Volume 2 Nomor 2, Desember 2019

E-ISSN : 2655-7347

\title{
ANALISIS TERHADAP PERMASALAHAN HUKUM PENGUASAAN TANAH DENGAN HAK GUNA USAHA DI KALIMANTAN (STUDI PUTUSAN: PUTUSAN MAHKAMAH AGUNG NOMOR 121 K/TUN/2017)
}

\author{
Nadhil Rifqi Izhhar \\ (Mahasiswa Program S1 Fakultas Hukum Universitas Tarumanagara) \\ (E-mail: nadhil_izhhar@yahoo.com)
}

\begin{abstract}
Dr. Hasni, S.H, M.H.
(Corresponding Author)

(Dosen Fakultas Hukum Universitas Tarumanagara. Meraih Sarjana Hukum pada Fakultas Hukum Universitas Krisnadwipayana, Magister Hukum pada Fakultas Hukum Universitas Indonesia)

(E-mail: hasni@fh.untar.ac.id)
\end{abstract}

\begin{abstract}
The law of the land Indonesia in the act of no. 51960 basic provisions concerning this agrarian law based on article 33 paragraph 3 constitution of the Republic of Indonesia 1945. In long-term development the role of land to meet various purposes will increase, good as a live and for business activities. The high level of demand will ground, present us on various problems quaint and still unsolved in an unsatisfactory manner for all parties. Usage rights business have had the use as agricultural land, fisheries, or farmers usage rights a business are also was in directly controlled by the state with a term 25 years or 35 years old and if necessary it could be prolonged 25 years, the broad at least usage rights business at least 5 acres. The various kinds of problems land around land and land together have a Cultivation Rights Title itself such a delicate and complicated it feels conflict land that is just keep on coming from the opening of the land and forest, damage to the customary overlapping permission and many other conflict certain harming other parties. The results of the investigations and analysis Forest Watch Indonesia has indicated the occurrence of violations of related to the licensing of some companies by the district government Long Bentuq area. Forest watch indonesia found the existence of overlapping permission between companies the oil palm with a company from various sectors which are all active operating in the same location but it happened to the forest customary, eviction cemetery land and sengon and cocoa plantations belonging to society is in the village Long Bentuq. The approach used by the writer among others is the approach comparative and law.
\end{abstract}

Keywords: Cultivation Rights Title, Informastion Disclosure, Agrarian Conflict

\section{PENDAHULUAN}

\section{A. Latar Belakang}

Sejak berdirinya Negara Kesatuan Republik Indonesia telah mengindikasikan dirinya agar jadi Negara yang punya dasar hukum. Karena negara yang punya dasar hukum, negara dan pemerintahan Indonesia dibangun untuk melindungi seluruh 
bangsa serta tumpah darah masyarakat dan negara Indonesia juga untuk memajukan kesejahteran umum, dan mewujudkan masyarakat yang adil, makmur serta merta, memberikan jaminan untuk menimbulkan perlindungan hukum bagi warga negara yang prinsip negara hukum telah ditegaskan dalam Pasal 1 Ayat 3 Undang-Undang Dasar Negara Republik Indonesia 1945 yang mana menyatakan bahwa Indonesia adalah Negara hukum.

Bumi, air, dan ruang angkasa serta segala kekayaan alam yang berada di dalamnya merupakan rahmat yang diberikan oleh Tuhan Yang Maha Esa kepada seluruh rakyat Indonesia maka dari itu pemanfaatan fungsi dari bumi, air, dan ruang angkasa beserta seluruh yang terkandung di dalamnya ada ditujukan untuk gapaian besar kemakrnuran rakyat Indonesa sepertii yang tercantum pada Pasa1 33 ayat (3) UUD1945, yaitu:

"Bumi juga air serta kekayaan alam yang terkandung di dalamnya dikuasai sama Negara dan gunakan untuk besar kernakmuran rakyat."

Sedangkan 33 ayat (3) Undang - Undang Dasar 1945 hal ini rnerupakan pijakan konstitusional bagi Hukum Agraria Nasional. Tanah rnerupakan hal yang penting untuk kehidupan bangsa Indonesia, dalam hal untuk memenuhi kebutuhan rnanusia sebagai lokasi untuk tinggal atau bagi lokasi untuk melaksanakan aktifitas usaha yang pada awalnya hanya digunakan untuk tempat tinggal atau bisa juga pemukiman serta sebagai lahan untuk mengelola pertanian. Seiring perkembangan karena semakin meningkatnya kebutuhan hidup manusia, pertambahan jumlah penduduk, perkembangan teknologi dan pertumbuhan ekonomi maka tanah juga difungsikan sekarang sebagai tempat untuk kegiatan industri, kegiatan usaha lain, bangunan-bangunan komersial dan lainnya.

Penguasan Negara atas tanah harus dilihat dari dasar pada butuh dan kesejahteran bangsa Indonesia sebagaimana konstitusi mengamanat kesejahteran kepada rakyat lndonesia. Tapi dalam pengelolaan yang masukan dengan sejahteran rakyat juga perlu tambah dengan ada sebuah patuh hukum yang dilakukan oleh 
rakyat kepada mengelola tersebut. ${ }^{1)}$ Tanah Nasional (HTN) yang ketentuan utama terdapat didalam Peraturan Dasar Utama Agraria (yang selanjutnya disebut UUPA) merupakan basic dan landasan hukum untuk punya dan kuasai tanah oleh orang lain dan perusahaan dalam rangka terpenuhi keperluannya, untuk bisnis ataupun bangunan.

Permukaan ketentuan hak-hak atas tanah sendiri diatur dalarn Undang-Undang Pokok Agraria berdasarkan dasar menguasai yang disebutkan dalam Pasal 4 ayat 1 menguasai oleh Negara Kesatuan Repubik Indonesia ditentukan adanya ragamragam hak atas muka bumi yang disebut tanah, yang bisa diberi kepada dan dipunyai oleh orang-orang, baik dipunyai sendiri maupun bersama-sama dengan orang-orang lain serta badan-badan hukum. Atas dasar ketentuan Pasal 4 ayat (2) UUPA dalam hal ini diberikan wewenang untuk gunakan tanah yang bersangkutan. Tanah tersebut digunakan dalam batas-batas yang telah ditentukan oleh UUPA dan peraturan-peraturan hukum lain yang lebih tinggi.

Bahwa dalam hukum tanah nasional ada bermacam-macam hak penguasaan atas tanah yang mana dapat disusun dalam jenjang tata susunan atau hierarkhi sebagai berikut: Hak Bangsa Indonesia, Hak Menguasai dari Negara, Hak Ulayat masyarakat-masyarakat adat, sepanjang menurut kenyataan masih ada, Hak-hak Individual. $^{2)}$

Tanah merupakan peranan penting dalam kehidupan masyarakat karna memiliki fungsi ganda. tanah dapat berfungsi sebagai social asset yang merupakan sarana yang dapat mengikat kesatuan dalam kalangan masyarakat Negara Republik Indonesia untuk hidup bersama-sama dalam masyarakat. Tanah juga dapat berfungsi sebagai capital asset dimana tanah dapat menjadi faktor dalam modal pembangunan Negara Republik Indonesia karna dapat menarik investor-investor untuk mengelola dan memberikan pendapatan baik untuk masyarakat sekitar

\footnotetext{
${ }^{1)}$ Denico Doly, Kewenangan Negara dalam Penguasaan Tanah: Redistribusi Tanah Untuk Rakyat, hal. 6

2) Boedi Harsono, Hukum Agraria Indonesia, (Jakarta: Djambatan, 2003), hal. 267.
} 
Volume 2 Nomor 2, Desember 2019

maupun Negara Indonesia dan dalam penggunaannya tanah harus dimanfaatkan dengan baik sehingga dapat berguna dan bermanfaat sebesar-besarnya untuk bangsa dan negara juga dapat mensejahterakan rakyat Indonesia sebagaimana mestinya Negara Republik Indonesia mensejahterakan rakyat secara baik dan adil juga merata keseluruh elemen lapisan masyarakat. ${ }^{3)}$

Untuk bangunan jangka panjang, tanah berperanan sebagai pernenuhan keperluan yang akan rneningkat tajam, baik sebagai ternpat tinggal rnaupun untuk kegiatan masyarakat mencari nafkah bahkan untuk tempat manusia dikubur, dengan demikian akan terjadi juga meningkatnya keinginan jarninan atas kepastian hukum pertanahan dimana dengan tingginya kebutuhan akan tanah tersebut maka dukungan atas jaminan kepastian hukurn pertanahan sangat dibutuhkan. Tersedianya perangkat hukum tertulis yang lengkap dan jelas akan mendukung dari kepastian hukum bidang pertanahan ini selain itu pelaksanaan secara konsisten yang sesuai dengan peraturan yang mengaturnya akan menambah jaminan akan kepastian dibidang hukum tersebut. ${ }^{4)}$

Tingginya tingkat permintaan akan tanah, menghadapkan kita pada berbagai permasalahan pelik dan belum terpecahkan secara memuaskan bagi semua pihak. Manusia yang terus bertambah jumlahnya tidak berimbang dengan persedian tanah bahkan butuhkan tanah itu sendiri telah menimbulkan banyak dan beragam permasalahan delik yang mana belum terpecahkan serta tidak memuaskan bagi semua pihak. Tidak berimbangnya jumlah tanah persediaanya yang ada dengan kebutuhan masyarakat atau kebutuhan lainnya akan tanah itu timbul banyak macam segi-segi persoalan yang terjadi. ${ }^{5)}$

3) Achmad Rubaie, Hukum Pengadaan Tanah Untuk Kepentingan Umum, (Malang: Bayumedia Publishing, 2007), hal. 1.

4) Sunario Basuki, Ketentuan Hkum Tanah Nasional (HTN) yng Menjadi Dasar dan Landasan Hkum Pemilikan dan Penguasaan Tanah (Program Pendidikan Spesialis Notariat Fakultas Hukum Universitas Indonesia), hal. 1.

5) Soehadi, Penyelesaian Sengketa tentang Tanah, sesudah berlakunya Undang-Undang Pokok Agraria, usaha Nasional, (Surabaya: Usaha Nasional 1989). 
Semua ketentuan yang terkait dengan tanah, diatur dengan UUPA, termasuk mengenai Hak Guna Usaha (yang selanjutnya disebut HGU). HGU merupakan suatu hak diberikan untuk tanah digunakan yang dikuasai langsung oleh Negara Republik Indonesia dalam bidang pertanian, perikanan ataupun perternakan, HGU merupakan hak yang mempunyai sifat primer yang mernilikii spesifikasi. syarat di dalam HGU tidak bersifat yang terkuat dan yang terpenuh, yang memiliki artian bahwa HGU ini terbatas daya berlakunya karna memiliki batas walaupun waktu beralih dialihkan pihak lain menjelaskan dalam UU PA telah dipakai sama sendirinya kalau HGU tersebut sebagai hak-hak baru guna masyarakat modern memenuhi dan HGU hanya dapat diberikan terhadap tanah yang dikuasai langsung oleh Negara. Harus tidak dapat jadi atas suatu perjanjian antara pemilik suatu hak milik dengan orang lain, mengenai HGU sudah terdapat aturan lebih lanjut sejak dikeluarkannya Peraturan Pernerintah Nomor 40 Tahun 1996 tentang Hak Guna Usaha, Hak Guna Bangunan dan Hak Pakai Atas Tanah (yang selanjutnya disebut PP 40 tahun 1996). ${ }^{6)}$

HGU memiliki tujuan penggunaan sebagai lahan pertanian, perikanan, atau pertenakan HGU juga merupakan tanah yang Negara kuasai secara dengan batas waktu dua puluh lima tahun atau tiga puluh lima tahun dan bila perlu HGU dapat diperpanjang lagi dua puluh lima tahun, batas luas minimal HGU sedikitnya 5 hektar. ${ }^{7)}$ Para pemegang HGU juga memiliki kewajiban membuat uang pemasukan kpada Negara serta pemegang HGU untuk melaksnakan usaha tani, kebun perikanan, dan/atau pertenakan sesuai dengan kegunaanya dan persyaratan sebagaimana ditetapkan dalam keputusan pemberian hak HGU untuk membangun dan memelihara prasarana lingkungan dan fasilitas tanah yang ada dalam lingkungan area HGU, memelihara kesuburan tanah dan mencegah kerusakan sumber daya alam dan menjaga kelestarian kemampuan lingkungan hidup sesuai

\footnotetext{
6) Supriadi, Hukum Agrria, (Jakarta: Sinar Grafika, 2008), hal.110.

7) Wantjik Saleh, Hak Anda Atas Tanah, (Jakarta: Ghalia Indonesia, 1985), hal. 39.
} 
aturan perundang-undangan yang berlku, menyampaikan laporan-laporan tertulis setiap akhir tahun yang berisi penggunaan HGU, mengembalikan kembali tanah yang diberikan kepada Negara setelah HGU tersebut hapus, menyerahkan sertipikat HGU yang telah hapus kepada Kepala Kantor Pertanahan. ${ }^{8)}$

Adanya berbagai macam masalah pertanahan di sekitar lahan yang bersinggungan maupun lahan yang memperoleh HGU itu sendiri sedemikian rumit dan pelik hal ini terasa sekali dari konflik-konflik pertanahan yang selalu bermunculan mulai dari pembukaan hutan dan lahan masyarakat, rusaknya hutan adat sampai tumpang tindih izin perusahaan dan banyak konflik-konflik lainnya yang mengakibatkan kerugian pihak-pihak tertentu.

Hasil investigasi dari Forest Watch Indonesia (yang selanjutnya disebut FWI) telah menganalisis bahwa terindikasi telah terjadinya pelanggaran yang berkaitan dengan pemberian izin untuk beberapa perusahaan yang izin tersebut diberikan pemerintah kabupaten Kutai. FWI mengindikasikan terdapat turnpang tindh perizinan antar perusahan kebun sawit dengan perusahan dari berbagai sector yang banyak aktif beroperasi di lokasi yang sarna selain itu terjadi juga pengusuran hutan adat, bidang-bidang makam dan perkebunan sengon dan kakao rnilik rnasyarakat ada di Desa Long Bentuq. ${ }^{9)}$

Terjadinya konflik pertanahan yang timbul dapat membuat kesan bahwa tanah yang sering disebut sebagai sumber kemakmuran rakyat dan sebagai simbol kesejahteraan masyarakat seakan-akan sudah berubah menjadi sumber pemicu timbulnya konflik dalam masyarakat, kerawanan masalah sengkta hukum atas tanah di negara kita, tidak saja terletak kelemahan dan kekurangan peraturanperaturan di bidang pertanahan, melainkan juga disebabkan oleh manusia, khususnya para pelaksanaan dibidang opsional dan kekurang pahaman warga masyarakat mengenai hak dan kewajiban menurut hukum.

\footnotetext{
8) Sahnan, Hukum Agraria Indonesia, (Malang: Setara Press, 2016), hal. 85.

9) Siaran Pers Forest Watch Indonesia (http://fwi.or.id/publikasi/petaka-akibat-karut-marut-sistimperizinan-di-kabupaten-kutai-timur/) Diakses 6 Agustus pukul 19.00 WIB
} 
Presiden Jokowi menerbitkan Peraturan Presiden Repblik lndonesia No. 86 Tahun 2018 tentang Reformasi Agraria, terbitnya Peraturan Presiden atas pertimbangan untuk mewujudkan pemerataan struktur penguasaan, pemilikan, penggunaan dan pemanfaatan tanah untuk kemakmuran rakyat Indonesia.

Pada hakikatnya, reforma agraria memiliki konsep yang mencakup konsep landreform, dimana didalam konsep ini penataan kernbali strukturstruktur penguasan atas kepernilikan tanah yang merata sehingga kepemilikan tanah dapat terbagi dengan adil, selanjutnya terdapat konsep acces reform, yang memiliki kaitan dengan pemanfaatan tanah agar lebih produktif penggunaannya serta menata dukungan fasilitas yang dapat memungkinkan petani untuk dapat memperoleh jalan (akses) ke sumber ekonomi di wilayah pedesan. Fasilitas srana dan prasaraana tersebut dapat berupa irigasi, akses jalan, bantuan pemasaran, keredit usaha rakyat atau koncep policy (regulation reform) yang mengatur kebijakan dan hukum yang berpihak kepada masyrakat ${ }^{10)}$ Dengn adanya Reforma Agraria tersebut redistribusi tanah sejatinya memakmurkan masyarakat tetapi yang terjadi samapai sekarang capaian reforma agraria masih berputar-putar di percepatan pembagian sertifikat tanah.

Banyaknya kasus-kasus sengketa hukum yang berlainan versinya mengakibatkan munculnya konflik agraria yang sering terjadi di kawasan-kawasan yang banyak ditumpangi izin-izin usaha seperti izin usaha pemnfaatan hasil hutan kayu kepada hutan taman satu biasa dibilang Hutan Taman Industri (HTI), izin pada lokasi perusahaan perkebunan kelapa sawit, serta pencabutan kawasan hutan dan berbagai proses perizinan dalam HGU lainnya, hal tersebut berkaitan erat dengan terbatasnya informasi yang dapat diperoleh oleh masyarakat luas.

Dalam terjadinya keterbatasan informasi tersebut Mahkamah Agung Republik Indonesa dalam putusannya Nomor 121K/TUN/2017 yang menguatkan putusan

10) Muhammad Ilham Arisputera, Reforma Agraria Indonesia, (Jakarta: Sinar Grafika, 2015), hal. 21 . 
KIP Republik Indonesa Nomor:057/XII/KIP-PS-MA/2015 dalam sengketa ini FWI sebagai Pemohon memohonkan terhadap Termohon yang dalam sengketa ini Kementerian ATR/BPN. FWI sbagai pemhon pada tahun 2015 ajukan memohonkan informasi publik yang pilih terhadap Pejabat kelola lnfomasi dan Dokumen (PPID) Kementerian ATR/BPN yang diterima seorang termohon, informasi yang dimohonkan berupa dokumen HGU komoditas kebun di Kalimantan bahwa hingga batas waktu memberikan jawaban atas permohonan informasi yang telah diatur dalam Undang-Undang Nornor 14 Tahun 2008 Tentang Keterbukan Informasi Publik (yang selanjutnya disebut UUKIP) telah berakhir termohon tidak memberikan jawaban sehingga pemohon mengajukan keberatan yang telah diterima dan berakhir tidak diberikannya tanggapan oleh termohon, dengan tidak diberikannya tanggapan oleh termohon, pemohon mengajukan permohonan penyelsaian masalah informasi publik ke KIP, dalam permohonan tersebut pemohon memperjelas informasi yang dimohonkan berupa Daftar Dokumen HGU untuk Perkebunan khusus untuk komoditi jenis Kelapa Sawit di Kalirnantan Tengah, Kalirnantan Barat, Kalirnantan Timur, Kalirnantan Selatan, dan Kalirnantan Utara yang rnemuat rincian inforrnasi meliputi: siapa dari Pernegang Izin HGU, Ternpat atau Lokasi HGU berada, Luas HGU yang telah diberikan, Jenis Kornoditi yang diberikan, Peta Arial HGU yang dilengkapi titik kordinat.

Diajukannya permohonan tersebut dan telah diputus oleh Komisi Informasi Pusat dikuatkannya dengan putusan Mahkamah Agung Republik Indonesia permohonan pemohon dikabulkan, tetapi hingga putusan Mahkamah Agung Republik Indonesia tahun 2017 sampai dengan sekarang putusan tersebut tidak dilaksanakan.

Sangat pentingnya tanah untuk kehidupan manusia di muka bumi ini membuat setiap manusia berusaha mempunyai dan menguasinya. Adanya keinginan tersebut dapat menimbulkan suatu konflik tentang tanah didalam masyarakat. Konflik 
Volume 2 Nomor 2, Desember 2019

Pertanahan di Indonesa tidak bias di diselesaikan dengan rnenggunakan hukurn saja, pendekatan secara holistic (komprerehensif) seperti pendekatan politik bagaimana menimbang kepentingannya selain itu dengan sosial budaya yang melihat aspek-aspek sekitar serta kesejahteraan atau aspek ekonomi juga perlu diperhatikan.

Tidak kalah penting adalah untuk menangani dan menyelesaikan konflik terjadi sangat penting untuk didukung oleh kelembagaan pertanahan yang baik, saling koordinasi antar kelembagaan pemerintah yang efektif dapat membantu penyelesaian masalah secara cepat. ${ }^{11)}$

Dalam menyelenggarakan pemerintahan, good governance merupakan formula yang telah ada, good governance merupakan suatu asas atau prinsip yang seharsnya menjadi acuan untuk pemerintahan dalarn negara berbentuk dernokrasi rnodern, yang seharunya penyelengaraan pernerintahan rnengedepankan prinsip partisipasii masyarakat, terbukaan pemerintahan, dan akuntablitas yang jelas. ${ }^{12)}$

\section{B. Perumusan Masalah}

Berdasarkan latar belakang diatas, maka perumusan masalah dalam penelitian ini adalah:

1. Bagaimana pengaruh keterbukaan informasi pemegang hak guna usaha terhadap terjadinya konflik agraria di Kalimantan?

\section{Metode Penelitian}

Suatu unsur mutlak merupakan metode yang harus ada dalam suatu penetilitan yang berfungsi untuk mengernbangkan ilmu pengetahuan. ${ }^{13}$ ) Untuk mengembangkan ilmu pengetahuan khususnya di bidang hukurn diperlukanlah peneltian hukurn. Penelitian hukum rnerupakan suatu kegiatan ilmiah yang didasarkan pada metode, sistematika dan pemikiran tertentu yang bertujuan untuk

11 ) Muhammad Ilham Arisaputra, Penerapan Prinsip-Prinsip Good Governance dalam Penyelenggaraan Reforma Agraria di Indonesia, Jurnal Yuridika: Volume 28 No 2, hal. 2

12) Ibid., hal. 4-5

13) Soerjono Soekanto, Pengantar Penelitian Hukum, (Jakarta: UI Press, 1981), hal. 7. 
mempelajari satu atau beberapa gejala hukum tertentu dengan menganalisanya. Untuk mengetahui masalah-masalah dan agar penulis bisa melakukan evaluasi permasalahaan yang telah disebutkan sebelurnnya, sehingga dalarn pengurnpulan isi serta fakta-fakta, dan data yang diperlukan penulis rnenggunakan metode yaitu sebagai berikut:

1. Jenis Penelitian

Jenis penelitian yang digunakan pada penelitian ini bersifat yuridis normatif, oleh karena didasarkan pada metode, sistematika dan pemikiran tertentu dengan tujuan mempelajari suatu data yang akurat dan relevan dengan permasalahan yang diteliti maka penulis menggunakan rnetodologi penelitian hukurn normatif dengan pendekatan studi kepustakaan (library research) yang rnenggunakan bahan pustaka. ${ }^{14)}$

2. Jenis dan Sumber Data

Sebagaimana jenis penelitian yang digunakan adalah penelitian hukum normatif maka jenis data yang digunakan adalah data sekunder yang dilakukan dengan studi pustaka terhadap bahan-bahan hukum dan bahan nonhukum. Sumber data yang digunakan antara lain:

a. Bahan Hukum Primer, yaitu bahan hukum yang mengikat dan terdiri dari:

1) Undang-Undang Dasar Negara Republik Indonesia Tahun 1945

2) Undang-Undang Nomor 5 Tahun 1960, tentang Peraturan Dasar PokokPokok Agraria;

3) Undang-Undang Nomor 14 Tahun 2008 tentang Keterbukaan Informasi Publik

4) Peraturan Pemerintah Nomor 40 Tahun 1996 tentang Hak Guna Usaha, Hak Guna Bangunan dan Hak Pakai Atas Tanah;

14) Peter Mahmud Marzuki, Penelitian Hukum, Cetakan ke-1, (Jakarta: Kencana Prenada Media Group, 2006), hal. 35. 
5) Peraturan Menteri Agraria dan Tata Ruang/Kepala Badan Pertanahan Nasonal Nomor 7 Tahun 2017;

6) Putusan Komisi InformasiPusat Nomor 057/XII/KIP-PS-MA/2015

7) Putusan Mahkamah Agung Nomor 121 KTUN/2017

b. Bahan Hukum Skunder, yaitu bahan-bahan hukum yang tidak mengikat namun memberikan penjelasan perihal bahan hukurn primer dan membantu proses pemahaman dan penganalisaan bahan hukurn prirner, antara:

1) Literatur yang berkaitan dengan Agraria dan Keterbukaan Informasi.

2) Buku yang berkaitan dengan Agraria dan Keterbukaan Informasi.

c. Bahan Hukum Tersier, yang dipergunakan adalah bahan-bahan yang memberi penjelasan terhadap bahan hukum primer dan sekunder yaitu Kamus hukum.

d. Bahan Non-Hukum, yaitu bahan-bahan penunjang diluar bahan hukurn prirmer dan sekunder sebagai bahan pelengkap bukan yang utarna serta mernberikan petunjuk tarnbahan terhadap bahan-bahan hukurn tersebut yaitu berupa Kamus Besar Bahasa Indonesia (KBBI) dan wawancara dengan narasurnber (ahli hukum) sebagaii upaya rnendapatkan pendapat hukum tentang objek yang diteliti.

3. Teknik Pengurnpulan Data

Teknik pengurnpulan data melalui studi dokumen atau bahan pustaka (library research) yaitu alat pengumpulan data tertulis dengan mempergunakan content analysis yaitu setiap teknik untuk membuat inferensi secara objektif dan sistematis untuk mengidentifikasi karakteristik pesan yang spesifik.

4. Teknik Pengolahan Data

Setelah data dan bahan hukum dikumpulkan, dilakukan pengolahan data yaitu rnengolah data sedemikian rupa sehingga data dan bahan hukum tersebut tersusun secara runtun dan sistematis kedalam kelas-kelas dari gejala-gejala 
yang sama sehingga memudahkan peneliti dalam melakukan analisis. Pengolahan data seperti ini disebut sebagai klasifikasi.

5. Analisis Data

Analisis data dilakukan secara kualitatif yaitu data yang diperoleh diuraikan dalam bentuk kalimat-kalimat yang disusun secara sistematis. Data yang diperoleh akan menjadi kesimpulan mengenai masalah yang dibahas.

\section{PEMBAHASAN}

Berawal dari permohonan Informasi Publik melalui Surat Nomor 07/FWI/IX/2015, tertanggal 15 September 2015 yang diajukan oleh pemohon yang dalam kasus ini adalah Forest Watch Indonesia yang ditunjukan kepada Pejabat Pengelolan lnformasi dan Dokumentasi (PPD) Kementerian Agraria dan Tata Ruang/Badan Pertanahan Nasional yang diterima Termohon dalam kasus ini Kemeterian Agraria dan Tata Ruang/ Badan Pertanahan Nasional pada tanggal 16 Sepetember 2015, adapun informasi yang dimohonkan sebagai berikut:

a. Dokurnen Hak Guna Usaha (HGU) untuk perkebunan di Kalirnantan Tengah;

b. Dokumen HGU untuk perkebunan di Kalimantan Barat;

c. Dokumen HGU untuk perkebunan di Kalimantan Timur;

d. Dokumen HGU untuk perkebunan di Kalimantan Selatan;

e. Dokumen HGU untuk perkebunan di Kalimantan Utara.

Bahwa hingga batas waktu dalam memberikan jawaban atas permohonan informasi sebagaimana yang dimohonkan pemohon yang tekah ditentukan Undang-Undang Keterbukaan Informasi (UU KIP) Berakhir, termohon tidak memberikan jawaban, pemohon kemudian mengajukan keberatan melalui surat Nomor 02/FWI/X/2015, tertanggal 5 Oktober 2015 yang telah diterima termohon pada tanggal 6 Oktober 2015. Hingga batas waktu dalam memberikan tanggapan atas keberatan yang diajukan pemohon berakhir, termohon tidak memberikan tanggapan, sehingga pada tanggal 1 Desember 2015, pemohon mengajukan 
Permohonan Penyelesaian Sengketa Informasi Publik ke Komisi Informasi Pusat yang diterima dan terdaftar di kepaniteraan komisi informasi pusat pada tanggal yang sama dengan registrasi sengketa Nomor: 057/XII/KIP-PS/2015.

Terhadap sengketa a quo, Majelis Komisioner melalui panitera pengganti telah memanggil pemohon dan termohon untuk menghadiri sidang penyelesaian sengketa informasi publik pada tanggal 18 Februari 2016, 22 Februari 2016, 7 Maret 2016, 15 April 2016 dengan agenda pemeriksaan awal. Pada tanggal 27 April 2016 dilaksanakan penyelesaian sengketa informasi publik melalui proses mediasi yang menghasilkan tidak tercapainya kesepakatan (Mediasi Gagal) dikarenakan ketidakhadiran termohon dan pemohon menarik diri dari proses mediasi, Majelis komisioner menilai yang memeriksa sengketa memanggil kedua belah pihak untuk melanjutkan proses penyelesaian sengketa melalui proses Ajudikasi Nonlitigasi.

Sebagaimana dalam kesimpulan termohon yang pada pokoknya menyatakan informasi yang dimohon pemohon kecuali tentang Nama Pemegang Izin HGU bersifat terbuka dan dapat diberikan kepada pemohon, sehingga informasi yang menjadi sengketa a quo yang akan dipertimbangkan oleh Majelis Komisioner hanya berkaitan dengan Nama Pemegang Izin HGU yang dikecualikan termohon.

\section{Pendapat Majelis:}

Berdasarkan fakta yang diperoleh didalam persidangan sehingga menjadi fakta hukum bahwa termohon dalam sengketa a quo mengecualikan informasi tentang Nama Pemegang Izin HGU, oleh karena itu Majelis Komisioner hanya akan mempertimbangkan informasi tentang Nama Pemegang Izin HGU, termohon mendalilkan mengecualikan informasi Nama Pemegang Izin HGU berdasarkan Pasal 17 huruf b UU KIP terkait dengan persaingan usaha tidak sehat dan Pasal 17 huruh UU KIP terkait rahasia pribadi dan kondisi aset. Dalam pemeriksaan setempat termohon menguasai informasi dokumen HGU yang memuat Nama 
Pemegang Izin HGU yang dimohonkan pemohon yang tertuang dalam buku tanah yang juga diantaranya terdapat data fisik berupa: Nama Pemegang Izin HGU, Letak batas dan luas, dan juga keadaan tanah yang menerangkan peruntukan keperluan pemberian izin perkebunan kelapa sawit yang termuat dalarn surat ukur tanah dan melekat pada buku tanah tersebut. Terhadap dalil termohon yang menyatakan informasi Nama Pemegang Izin HGU jika dibuka dapat rnenimbulkan persangan usaha tidak sehat sebagamana PasaI 17 huruf b UU KIP, Majelis Komisioner menilai bahwa Narna Pernegang HGU dalarn data fisk yang ada dalam dokurnen HGU yang diterbitkan berdasarkann kebijakan yang dibuat oleh termhon tidak memuat informasi yang berkaitan dengan rencana bisnis, praktik bisnis dan perjanjian bisnis yang dimiliki oleh pemegang izin HGU, sehingga alasan pengecualian informasi a quo yang didalilkan termohon tidak memuat inforrnasi yang patut dikecualikan berdasarkan Pasal 17 huruf b UU KIP, sehingga dalil termohon sepatutnya tidak dapat diterima, sedangkan terhadap dalil termohon yang menyatakan informasi Nama Pemegang Izin HGU jika dibuka dapat menimbulkan data pribadi dan kondisi aset maka Majelis Komisioner menyatakan bahwa yang dimaksud dengan data pribadi berdasarkan ketentuan Pasal huruf h yitu:

a. Sebuah. sejarah dan kondisi anggota keluarga;

b. riwayat, kondisi dan perawatan, perawatan kesehatan fisik dan psikologis seseorang;

c. kondisi keuangan, aset, pendapatan, dan rekening bank seseorang;

d. hasil evaluasii terkait dengan kemampuan, kecerdasan, dan kernampuan seseorang untuk direkomendasikan; dan / atau

e. catatan yang berkaitan dengan orang dari seseorang yang berkaitan dengan kegiatan pengaturan pendidikan formal dan unit pendidikan non-formal.

Majelis Komisioner berpendapat bahwa informasi publik berupa Nama Pemegang Izin HGU merupakan produk kebijakan yang dikeluarkan oleh termohon untuk memberikan izin HGU kepda warga Indonesia dan/atau badn 
hukurn yang didrikan mnurut hukm Indonesia dan berkedudukan di Indonesia sebagai informasi publik sebagimana ketentuan Pasal 1 angka 2 dan Pasal 11 ayat (1) huruf c UU KIP juncto Pasal13 ayat(1) huruf b, dan g Peraturan Komisi Informasi Nomor 1 Tahun 2010 tentang Standar Layanan Informasi Publik (Perki SLIP) dan berdasarkan Putusan Kornisi Informasii Pusat terdahulu dalarn Putusan Nomor 218/VII/KIP-PS-MAA/2012, tertanggaI 30 Oktober 2013, antara lndra Reswanto, dkk terhadap PT Perkebuman Nusantara III (Persero) Kebun Serang Ginting, Serdang Begadai, Sumatera Utara. Informasi yang dimohonkan pemohon merupakan informasi publik yang bersifat terbuka, dengan amar putusan Mengabulkan permohonan FWI untuk seluruhnya, Membatalkan hasil pengujian konsekuensi informasi publik yang dilakukan KementerianATR/BPN nomor: 04/BA100/VI/2016, Menyatakan informasi yang dimohon FWI berupa daftar dokmen (HGU) komoditas kelapa sawit yang masih berlaku tahun 2016 dii Kalirnantan Tengah, Kalirnantan Barat, Kalirnantan Timur, Kalirnantan Selatan dan Kalirnantan Utara yang mernuat rincian lnformasi termasuk siapa memegang izin HGU, Ternpat atau lokasi HGU diberikan, Luas HGU yang diberikan, Jenis kornoditii HGU, Peta Arial HGU yang dilengkapi titik kordinat sebagai informasii yang bersifat terbuka untuk publik, serta memerintahkan Kementerian ATR/BPN untuk memberikan informasii yang dimaksud kepada FWI sejak putusan inii berkekuatan hukurn tetap (inkracht van gewijsde).

Majelis Komisioner berpendapat bahwa informasii publik berupa Nama Pemegang Izin HGU merupakan produk kebijakan yang dikeluarkan oleh termohon untuk memberikan izin HGU kepada warga Negara Indonesa dan/atau badan hukurn yang didirikan rnenurut hukurn Indonesia dan berkedukan sebagai informasi Indonesia seperti pasal 1 angka 2 dan Pasal11 ayat (1) huruf c UUKIP junctoPasal 13 ayat (1) huruf b, dan g aturan Komsi lnformasi Nomor 1 Tahun 2010 mengenai Standard Layanan Informasi Publik dan berdasarkan Putusan KIP terdahulu dalam Putusan Nmr 218/VII/KIP-PS-MA-A/2012, tertanggal 30 
Volume 2 Nomor 2, Desember 2019

Oktober 2013, antara lndra Riswanto, dkk terhadap PT Perkebunan Nusantaraa III (Persero) Kebun Seran Giting, Serdang Begada, Sumatera Utara. Informasi yang dimohonkan permintaan rnerupakan informasi publik yang bersifat terbuka.

Selanjutnya Kernenterian Agrraria dan Tata RuuangBaadan Pertanahan Nasinal terhadap putusan Komisi Informasi Pusat merasa tidak puas dan mengajukan keberatan atas putusan tersebut ke Pengadlan Tata Usaha Negra Jakarta, amar putusan Pengadilan Tata Usaha Negara Jakarta adalah rnenolak permohonan Kermeterian Agraria dan Tata Ruang dan Pertanahan Nasional dan menguatkan Putusan Komisi Informasi Pusat.

Selanjutnya pemohon memberatkan (Kementerian Agrraria dan Tata Raung/Badan Pertanhan/Nasonal) mengajukan permohonan kasasi saat tanggal 19 Desember 2016 sebagaimana memuat dalam Akta mohonan No 2G/KI/2016/PTUN.JKT., dengan menimbang hukum yang melakukan Majelis Hakim Mahkamah Agung Republik Indonesia nimbang bahwa Judex Facti (putusan Pengadilan Tata Usaha Negara Jakarta) sudah baik dan tidak salah diterapkan hukum, dengan timbangan bagaimana info yang mohonkan ke pemohonan kasasi berita dokumen administratif yang hubungan dengan Hak Guna Usaha (HGU) tidak memasuki info yang dikucilkan bagiyang bisa didapat kepada public sebagai disebut Pasal ll ayat (l) c Undang-Udang Nomr 14 Tahun 2018 mengenai Bukaan Info Publik.

Dengan pertimbangan hukum yang dilakukan Majelis Hakim Mahkamah Agung Republik Indonesia makan dengan itupula Majelis mengadili untuk menolak permohonan kasasi dari pemohon kasasi: Kementerian Agraria dan Tata Rang / Badan Pertanahan Nasional dan menghukum pemohon kasasi untuk membayar biaya perkara dalam tingkat kasasi sebsar Rp. 5.00.000,00 (lima ratus ribu rupiah). Hak-hak penguasaan atas tanah berisikan serangkaian wewenang, kewajiban dan/atau larangan bagi pemegang haknya untuk berbuat sesuatu dengan tanah yang haknya yang dikuasai. Hak-hak tersebutlah yang menimbulkan perbuatan-perbuatan yang dapat diperbuat 
ataupun dilarang untuk berbuat itulah yang menjadi tolak pembeda antara berbagai hak penguasaan atas tanah yang diatur dalam Hukum Tanah Negara yang bersangkutan.

Hak Guna Usaha karna sudah diputus oleh Komisi Informasi Pusat bahkan sampai dengan Mahkamah Agung bahwasannya informasi mengenai Hak Guna Usaha adalah informasi yang terbuka, Majelis Komisioner dari Komisi Informasi Pusat juga sudah berpendapat bahwasannya nama pemegang Hak Guna Usaha yang Hak Guna Kernenterian Agraria dan Tata Ruang/Badan tanah nasional tidak memuat lnformasi yang berkaitan dengan rencana bisnis, praktik bisnis, dan perjanjian bisnis yang dimiliki oleh pemegang izin Hak Guna Usaha sehingga dalil yang digunakan tidak dapat diterima, dalam proses setelah putusan Kasasipun Forest Watch Indonesia telah menunggu mekanisme dari permohonan informasi mengenai Hak Guna Usaha yang telah diputus terbuka hingga melakukan konfrontasi terhadap Kementerian Agraria dan Tata Ruang/Badan Pertanahan Nasional sampai akhirnya Forest Watch Indonesia melaporkan kepada Ombudsman, kesimpulan Ombudsman mengenai kasus ini yaitu Kementerian Agraria dan Tata Ruang/Badan Pertanahan Nasional terbukti Maladministrasi dan menyatakan harus segera membuat petunjuk teknis pemberian data mengenai Hak Guna Usaha tersebut tetapi sampai dengan saat ini rekomendasi tersebut tidak dilaksanakan. Menurut Bapak Agung jika memang panitia B sudah memastikan pemberian Hak Guna Usaha itu sudah bersih dari Hak lainnya maka seharusnya tidak terjadi lagi konflik-konflik mengenai Hak Guna Usaha, banyak temuan-temuan dari Forest Watch Indonesia mengenai konflik yang terjadi diatas lahan Hak Guna Usaha, selain tumpang tindih izin Hak Guna Usaha dengan izin pertambangan yang sering ditemui bahkan terdapat kasus gratifikasi berkaitan dengan penerbitan Kepala kantor wilayah dilibatkan badan pertanahan hak guna usaha Kalimantan Barat (2012-2016) dan Jawa Timur (2016-2018) dan bidang kepala tanah hak dan mendaftakan kantor tanah Badan Pertanahan Nasional yang telah ditetapkan tersangka oleh Komisi Pemberantasan Korupsi (KPK) untuk sejumlah perkebunan sawit di Kalimantan Barat yang diduga diterima dari para pemohon hak atas tanah 
Volume 2 Nomor 2, Desember 2019

termasuk pemohon Hak Guna Usaha selain itu di Kalimantan Barat juga Forest Watch Indonesia menemukan kawasan hutan lindung yang setelah dianalisa citra tutupannya adalah perkebunan sawit yang setelah ditinjau langsung benar adanya perkebunan sawit diatas hutan lindung yang setelah diperiksa.

Proses perolehan sampai dengan penggunaan Hak Guna Usaha inilah yang sering ditemui terdapat permasalahan atau konflik pertanahan, perselisihan yang terjadi dibidang tanah yang terdapat perbedaan nilai, kepentingan, pendapat dan/atau persepsi antara orang-orangan, bagian, organisasi, badan hukurn, atau lembaga yang mempunyai kecenderungan atau sudah berdampak luas serta mengandung aspek politis, ekonomi dan sosial budaya, konflik pertanahan yang terjadi khususnya terkait dengan Hak Guna Usaha berdasarkan laporan dari Forest Watch Indonesia terdapat beberapa perusahaan-perusahaan konsensi yang dimiliki izin Hak Guna Usaha itu masih memiliki persoalan terkait dengan kepastian lahan dan kepastian perizinan, tumpang tindih izin kemudian juga konflik dengan masyarakat termasuk di beberapa area dicurigai masih memiliki hutan alam, dengan temuan-temuan lapangan yang terjadi mendalilkan Forest Watch Indonesia untuk memverifikasi hal-hal tersebut hingga merasa perlu untuk adanya keterbukaan informasi mengenai data dan informasi mengenai Hak Guna Usaha, ketrbukaan iinformasi pblik adlah infrmasi yng dihaslkan, dismpan, diklola, diikirim, daan/atau dterima oleeh satu bdan publiik yng berkitan dngan penyelenggaraan negara dan/atau penyelenggara dan penyelenggaraan badan publik lainnya yang sesuai dengan Undang-Undang serta informasi lain yang berkaitan dengan kepentingan publik. Keterbukaan informasi dapat menjadi sarana dalam mengoptimalkan partisipasi publik terhadap penyelenggaraan Negara dan badan publik lainnya dan segala sesuatu yang berakibat pada kepentingan publik.

Keputusan Mahkamah Agung Republik Indonesia Nomor 121K/TUN/2017 yang menolak permintaan kasasi dari permohonan kasasi Kemetrian Agraria dan Tata Ruang atau Badan Pertanahan Nasional menyatakan bahwa informasi yang dimohonkan adalah daftar dokumen Hak Guna Usaha kebun kelapa sawit sebagai info yang bersifat 
terbuka, dan dalam aturan Keterbukaan Informasi Nomor 14 Tahun 2008 Pasal 11 menyatakan bahwa badan publik harus ada info publik setiap saat yang meliputi daftar semua informasi publik yang ada dibawah penguasanya termasuk yang kecuali jumlah putusan lembaga publik dan timbanganya, semua kebijakan terdapat berikut file Kementerian Lingkungan Hidup dan Kehutanan tidak terdapat pelepasan kawasan hutan sebagaimana yang telah diatur oleh aturan terkait, masalah tapal batas juga sering dijumpai dimana pemegang Hak Guna Usaha ditemui melebihi batas wilayah yang ditentukan sehinga harus bersitegang dengan masyarakat sekitar yang tanahnya digunakan sebagaimana tidak seharusnya dimana pemegang

Berdasarkan hasil wawancara dengan Bapak Hanafi Tanawijaya S.H., M.Hum, ATR/BPN seharusnya membuka data yaang diminta, karena bersama tidak terlaksanakan putusan tersebut menimbulkan kecurigan publik seperti ada yang salah dengan data yang tidak dibuka, karna dalam putusan tersebut sudah disebutkan bahwa infrmasi yaang diminta memohon merupakan informasi publik yang bersifat terbuka

Berdasarkan hasil wawancara dengan Bapak Agung selaku staff kampanye dan advokasi kebijakan Forest Watch Indonesia beliau mengatakan jika memang panitia B sudah memastikan pemberian Hak Guna Usaha itu sudah bersih dari Hak lainnya maka seharusnya tidak terjadi lagi konflik-konflik mengenai Hak Guna Usaha, banyak temuan-temuan dari Forest Watch Indonesia mengenai konflik yang terjadi diatas lahan Hak Guna Usaha salah satunya adalah pemegang Hak Guna Usaha yang melebihi tapal batas yang sudah ditentukan dimana pemegang Hak Guna Usaha melewati batas seharusnya menggarap tanah tersebut dimana dalam kasus itu menimbulkan konflik dengan pemilik tanah yang digarap tanahnya oleh pemegang Hak Guna Usaha, pemilik tanah yang tanahnya digarap reaktif terhadap kegiatan yang dilakukan pemegang Hak Guna Usaha hingga melakukan blokade dan meminta untuk pengukuran ulang Hak Guna Usaha tersebut dan benar adanya bahwasannya Hak Gna Ussaha terseebut lebih ditentukan oleh batas yang menggar sehingga letak dan besaran tanah Hak guna usaha yang didapat, mengenai info bahwasanya dibutuhkan agar menyelesaikan masalah 
Volume 2 Nomor 2, Desember 2019

yang ada dan kejadian di lahan ataupun sekitaran, terbukanya info pemegang hak guna usaha bias bikin melaksanakan hal-hal yang seharusnya diperbuat dan tidak melakukan perbuatan yang dilarang karena adanya partisipasi publik untuk dapat mengawasi.

Proses perolehan sampai dengan penggunaan Hak Guna Usaha inilah yang sering ditemui terdapat permasalahan atau konflik pertanahan, perselisihan yang terjadi dibidang tanah yang terdapat perbedaan nilai, kepentingan, pendapat dan/atau persepsi antara organisasi, badan hukurn, atau lembaga yang mempunyai kecenderungan atau sudah berdampak luas serta mengandung aspek politis, ekonomi dan sosial budaya, konflik pertanahan yang terjadi khususnya terkait dengan Hak Guna Usaha berdasarkan laporan dari Forest Watch Indonesia terdapat beberapa perusahaanperusahaan konsensi yang dimiliki izin Hak Guna Usaha itu masih memiliki persoalan terkait dengan kepastian lahan dan kepastian perizinan, tumpang tindih izin kemudian juga konflik dengan masyarakat termasuk di beberapa area dicurigai masih memiliki hutan alam, dengan temuan-temuan lapangan yang terjadi mendalilkan Forest Watch Indonesia untuk memverifikasi hal-hal tersebut hingga merasa perlu untuk adanya keterbukaan informasi mengenai data dan informasi mengenai Hak Guna Usaha, ketrbukaan iinformasi pblik adlah infrmasi yng dihaslkan, dismpan, diklola, diikirim, daan/atau dterima oleeh satu bdan publiik yng berkitan dngan penyelenggaraan negara dan/atau penyelenggara dan penyelenggaraan badan publik lainnya yang sesuai dengan Undang-Undang serta informasi lain yang berkaitan dengan kepentingan publik. Keterbukaan informasi dapat menjadi sarana dalam mengoptimalkan partisipasi publik terhadap penyelenggaraan Negara dan badan publik lainnya dan segala sesuatu yang berakibat pada kepentingan publik.

Dalam putusan Mahkamah Agung Nomor 121K/TUN/2017 yang menyatakan bahwa informasi yang dimohon oleh pemohon (Forest Watch Indonesia) berupa daftar dokumen Hak Guna Usaha perkebunan kelapa sawit yang masih berlaku di Kalimantan Tengah, Kalimantan Barat, Kalimantan Timur, Kalimantan Selatan dan Kalimantan Utara yang memuat rincian informasi meliputi: 
Volume 2 Nomor 2, Desember 2019

1) Nama pemegang izin Hak Guna Usaha

2) Tempat atau lokasi

3) Luas Hak Guna Usaha yang diberikan

4) Jenis komoditi

5) Peta arial Hak Guna Usaha yang dilengkapi titik kordinat.

Sebagai informasi yang bersifat terbuka, dan memerintahkan Kementerian Agraria dan Tata Ruang/Badan Pertanahan Nasional untuk memberikan informasi mengenai Hak Guna Usaha.

\section{PENUTUP}

\section{A. Kesimpulan}

Berdasarkan latar belakang, permasalahan, data hasil penelitian, serta analisis permasalahan yang telah diuraikan, maka dapat ditarik kesimpulan bahwa:

Permasalahan hukum yang terjadi atas bidang tanah dengan Hak Guna Usaha banyak dikaitkan dengan keterbukaan informasi mengenai daftar dokumen Hak Guna Usaha, adanya pihak-pihak yang merasa perlu adanya keterbukaan informasi mengenai Hak Guna Usaha itu untuk membantu mengawasi pembangunan dan pengelolaan lahan Hak Guna Usaha tersebut sesuai dengan seharusnya, bahkan terbukanya informasi daftar dokumen Hak Guna Usaha dapat membantu menyelesaikan konflik-konflik yang terjadi dengan masyarakat.

Dalam kasus yang berawal dari permohonan informasi hingga akhirnya diputus oleh Komisi Informasi Pusat dengan Putusan Nomor: 057/XXI/KIP-PSM-A/2015 yang memenangkan pemohon yaitu Forest Watch Indonesia yang menyatakan bahwa informasi yang dimohon berupa daftar dokumen Hak Guna Usaha perkebunan kelapa sawit yang masih berlaku di Kalimantan Tengah, Kalimantan Barat, Kalimantan Timur, Kalimantan Selatan dan Kalimantan Utara adalah informasi yang berisfat terbuka, keberatan yang dilayangkan oleh termohon (Kementerian Agraria dan Tata Ruang/Badan Pertanahan Nasional) ke 
Pengadilan Tata Usaha Negara Jakarta ditolak dan Putusan Komisi Informasi Pusat dikuatkan, hingga tahap selanjutnya Kementerian Agraria dan Tata Ruang mengajukan kasasi dan Majelis mengadili untuk menolak permohonan kasasi yang diajukan.

Dalam hal ini, apa yang dilakukan Kementerian Agraria dan Tata Ruang/Badan Pertanahan Nasional untuk tidak melaksanakan putusan yang sudah diputus oleh Komisi Informasi Pusat hingga dikuatkan oleh Mahkamah Agung Republik Indonesia sejak tahun 2017 adalah langkah yang menimbulkan kecurigaan publik seperti ada yang salah dengan data yang tidak dibuka oleh Kementerian Agraria dan Tata Ruang/Badan Pertanahan Nasional.

\section{B. Saran}

Oleh karena itu, ada beberapa hal yang menurut penulis perlu diperhatikan untuk semua pihak, untuk itu dengan segala keterbatasan pengetahuan yang ada, penulis mencoba menyumbangkan saran sebagai berikut :

1. Untuk Kementerian Agraria dan Tata Ruang/Badan Pertanahan Nasional, selaku badan publik yang mengeluarkan ijin Hak Guna Usaha dan merupakan badan publik yang menguasai informasi yang dimohonkan untuk membuka data informasi Hak Guna Usaha dan segera membuat petunjuk teknis pemberian data mengenai Hak Guna Usaha, dalam petunjuk teknis inilah Kementerian Agraria dan Tata Ruang/Badan Pertanahan Nasional dapat lebih selektif untuk memberikan data informasi Hak Guna Usaha tersebut, jika memang ditakutkan data ini di salah gunakan untuk hal yang tidak semestinya, Kementerian Agraria dan Tata Ruang/Badan Pertanahan Nasional dapat memberikan persyaratan-persyaratan dalam petunjuk teknis pemberian data mengenai Hak Guna Usaha, Kementerian Agraria dan Tata Ruang/Badan Pertanahan Nasional juga dapat meminta jaminan atas perolehan data informasi yang diberikan. 
Volume 2 Nomor 2, Desember 2019

E-ISSN : 2655-7347

2. Untuk Forest Watch Indonesia selaku pemohon data informasi Hak Guna Usaha, untuk terus mendesak Kementerian Agraria dan Tata Ruang/Badan Pertanahan Nasional membuka data informasi Hak Guna Usaha sebagaimana putusan Mahkamah Agung Nomor 121 K/TUN/2017, Forest Watch Indonesia juga dapat mengumpulkan data-data mengenai permasalahan hukum penguasaan tanah dengan Hak Guna Usaha secara spesifik dengan harapan data-data tersebut dapat menjadi temuan untuk mendorong Kementerian Agraria dan Tata Ruang/Badan Pertanahan membuka data informasi Hak Guna Usaha serta temuan tersebut dapat menjadi gambaran kepada masyarakat atas apa yang terjadi dengan penguasaan tanah dengan Hak Guna Usaha.

\section{DAFTAR PUSTAKA}

\section{A. Buku}

Arisputera, Muhammad Ilham. Reforma Agraria Indonesia. (Jakarta: Sinar Grafika, 2015).

Marzuki, Peter Mahmud. Penelitian Hukum. Cetakan ke-1. (Jakarta: Kencana Prenada Media Group, 2006).

Sahnan. Hukum Agraria Indonesia. (Malang: Setara Press, 2016).

Saleh, Wantjik. Hak Anda Atas Tanah. (Jakarta: Ghalia Indonesia, 1985).

Soehadi. Penyelesaian Sengketa tentang Tanah, sesudah berlakunya UndangUndang Pokok Agraria, usaha Nasional. (Surabaya: Usaha Nasional 1989). Soekanto, Soerjono. Pengantar Penelitian Hukum. (Jakarta: UI Press, 1981).

Supriadi. Hukum Agraria. (Jakarta: Sinar Grafika, 2008).

\section{B. Artikel Jurnal}

Arisaputra, Muhammad Ilham. Penerapan Prinsip-Prinsip Good Governance dalam Penyelenggaraan Reforma Agraria di Indonesia. Jurnal Yuridika: Volume 28. 
Volume 2 Nomor 2, Desember 2019

E-ISSN : 2655-7347

Basuki, Sunario. Ketentuan Hukum Tanah Nasional (HTN) yang Menjadi Dasar dan Landasan Hukum Pemilikan dan Penguasaan Tanah. (Program Pendidikan Spesialis Notariat Fakultas Hukum Universitas Indonesia).

Doly, Denico. Kewenangan Negara dalam Penguasaan Tanah: Redistribusi Tanah Untuk Rakyat.

\section{Website}

Anonim. "Forest Watch Indonesia" http://fwi.or.id/publikasi/petaka-akibat-karutmarut-sistim-perizinan-di-kabupaten-kutai-timur/. 6 Agustus 2019 